\title{
A VOZ DA ARGÉlIA. A PROPAGANDA REVOLUCIONÁRIA DA FRENTE DE LIBERTAÇÃO NACIONAL ARGELINA NO BRASIL. INDEPENDÊNCIA NACIONAL E REVOLUÇÃO SOCIALISTA (1954-1962)
}

The voice of Algeria. The revolutionary propaganda of the Algerian National Liberation Front in Brazil. National independence and socialist revolution (1954-1962)

La voz de Argelia. La propaganda revolucionaria de la Frente de Liberación Nacional argelina en Brasil. La independencia nacional y la revolución socialista (1954-1962)

RODRIGO NABUCO DE ARAUJO

http://dx.doi.org/10.1590/S2178-14942017000200006

Rodrigo Nabuco de Araujo é doutor em História pela Universidade Toulouse - Jean Jaurès, França, e professor associado do Departamento de Línguas Românicas da Universidade de Reims Champagne-Ardenne, França (rodrigo.nabuco-de-araujo@ univ-reims.fr).

O autor gostaria de agradecer as releituras de Maud Chirio, Eugenia Palieraki e Teresa da Silva Telles.

Artigo recebido em 1 de fevereiro e aprovado para publicação em 8 de maio de 2017. 


\section{RESUMO}

Este trabalho tem como objetivo apresentar novas perspectivas sobre as revoluções na América Latina e no Norte da África, analisando as circulações de pessoas e ideias de 1954 a 1962. Anterior à Revolução Cubana, a Guerra da Argélia (1954-1962) mobilizou os corações e mentes de políticos e intelectuais latino-americanos. Além de intelectuais argelinos, o movimento revolucionário contou com o apoio de letrados oriundos de outras colônias francesas, bem como da América Latina. Neste artigo enfatizamos a participação de intelectuais brasileiros. 0 ponto de partida é a atuação da Frente argelina de Libertação Nacional na América Latina através de seu órgão oficial, o jornal El Moudjahid, bem como de jornais brasileiros. Buscamos mostrar como pensadores socialistas das décadas de 1950 e 1960 discutiram a guerra de independência da Argélia.

Palavras-Chave: movimentos revolucionários; nacionalismo; socialismo; intelectuais; propaganda política; Frente de Libertação Nacional; Argélia.

\section{AbSTRACT}

This essay intends to shed a new light on the revolutions in Latin-America and Northern Africa, by examining how people and ideas circulated between those two poles, in particular between Brazil and Algeria from 1954 to 1974. Before the Cuban Revolution, the Algerian War (1954-1962) mobilized the hearts and the minds of politicians and Latin American intellectuals, just as much as during the Spanish Civil War 15 years earlier. In addition, the revolutionary movement had the support of Algerian intellectuals and scholars from other French colonies and from Latin-American countries. The main focus of this study is the role of the National Liberation Front in Brazil, through its official newspaper, El Moudjahid, as well as some Brazilian journals: we consider the debates shared in those texts, thus examining the discussion in intellectual circles from the 1950's to the 1960 's and how do they thought the Algeria independency war.

KeYwORDs: revolutionary movements; nationalism; socialism; intellectuals; political propaganda; National Liberation Front; Algeria.

\section{RESUMEN}

Este trabajo tiene como objetivo presentar nuevas perspectivas sobre las revoluciones en América Latina y en el norte de África, analizando las circulaciones de personas e ideas durante el período de 1954 a 1962. Antes de la revolución, la guerra de Argelia (1954-1962) movilizó corazones y mentes de políticos e intelectuales latinoamericanos. Además de los intelectuales argelinos, el movimiento revolucionario contó con el apoyo de los estudiosos de otras colonias francesas y de América Latina, en este artículo ponemos énfasis en la participación de intelectuales brasileños. El punto de partida de este estudio es el papel del Frente de Liberación Nacional de Argelia en América Latina, por medio de su órgano oficial, el diario El Moudjahid y periódicos brasileños. Pretende mostrar cómo los pensadores socialistas de los años 1950 y 1960 discutieron la guerra de independencia de Argelia.

Palabras clave: movimiento revolucionario; nacionalismo; socialismo; propaganda política; Frente de Liberación Nacional; Argelia. 
escopo deste trabalho é compreender a importância da revolução argelina na reconfiguração das redes de militantes entre a Argélia, o Brasil e a França, ao focar a atenção sobre intelectuais e jornalistas que cobriram a guerra. Explica-se de que maneira Argel se tornou um ponto de encontro das esquerdas revolucionárias. 0 objetivo é analisar discursos e trajetórias militantes e deslocar a tradicional análise da relação com movimentos revolucionários europeus para buscar o lugar da África.

Desde Cuba, recém-libertada da ditadura de Fulgencio Batista, até o Brasil de Goulart, com escala na Venezuela, no Chile e na Argentina, devem ser salientadas a trajetória e a atuação dessas pessoas, como por exemplo as de Jean-Paul Sartre e do padre Alfred Bérenguer. Sartre conta com extensa bibliografia sobre sua viagem pela América Latina (Caubet, 1986). A. Bérenguer permanece pouco conhecido, embora seu papel tenha sido crucial, pois de certa forma preparou o terreno para importantes discussões sobre a natureza da revolução argelina. Com efeito, a Argélia refletia as principais lutas dos anos 50 e 60: direito dos povos à autodeterminação, independência política e econômica, novas vias para se chegar ao socialismo.

0 trabalho de jornalistas foi crucial para levar ao público brasileiro notícias da guerra, interpretando seu conteúdo e dando sentido à revolução. Exilados das ditaduras salazaristas ou franquistas agiam como intermediários entre dois ou mais universos militantes: europeus, africanos e latino-americanos (Paulo, 2010). A trajetória de Francisco Cachapuz, conhecido pelo pseudônimo Paulo de Castro, é excelente exemplo: jornalista do Diário de Notícias, cobriu a luta de independência viajando à Argélia em guerra em 1957.

Muito do que acontecia resultava da atuação da Frente de Libertação Nacional (FLN). 0 eixo central de sua estratégia de independência era a propaganda exterior, cuja finalidade era sensibilizar a opinião de intelectuais e políticos no maior número possível de países. A FLN agia diretamente ao informar, sensibilizar e convocar o envolvimento dos "irmãos" que lutavam pela independência, por meio de partidos políticos e do movimento estudantil. Em 1956, o congresso de Soumann contemplaria a estratégia original elaborada pelos líderes argelinos, cujo objetivo era levar a luta ao campo político (Meynier, 2002: 158). A derrocada do núcleo militante em Argel, após duros combates contra as forças francesas, consolidou a ideia de que a vitória seria antes política. A versão editada em francês do jornal oficial, El Moudjahid, 1 tinha o objetivo de divulgar notícias da revolução e revelar sua verdadeira natureza (Fitte, 1973: 6). 
Rapidamente El Moudjahid se tornou um ponto de encontro de intelectuais e militantes anti-imperialistas e contou com a contribuição de europeus, africanos e latino-americanos. As questões mais importantes do momento eram ali tratadas: de um lado a democracia, a revolução, a contrarrevolução e o retorno ao antigo regime, de outro lado a exclusão social, o racismo e a opressão. A difusão de textos impressos, associada a estratégias de consolidação da cultura argelina, contribuiu para a difusão rápida e eficiente de novas ideias, que orientaram a construção da nação argelina. Autores e leitores que contribuíram para o jornal argelino escreviam também na imprensa brasileira, veiculando um ideal de luta pautado pela busca de independência nacional. Seguindo a análise do historiador Benedict Anderson, pode-se afirmar que em meados do século XX surgiu uma comunidade de pessoas que compartilhavam os mesmos ideais, falavam a mesma linguagem política e viviam momentos fundadores (Anderson, 2008). A guerra da Argélia e as discussões políticas e ideológicas que acompanharam seus desdobramentos contribuíram para reabilitar o ideal humanista da Revolução Francesa.

Este trabalho se apoia em artigos publicados por autores brasileiros no jornal oficial da FLN, mas também em textos publicados no Brasil por autores argelinos. Busca-se mostrar como se estabelecia o diálogo entre intelectuais e militantes que contribuíram para forjar novo ideal de luta anti-imperialista. Parte das fontes se encontra no Arquivo do Ministério das Relações Exteriores francês, o Quai d'Orsay, em particular a documentação dos adidos militares, cuja atuação na repressão à FLN foi fundamental. A pesquisa em documentação brasileira foi realizada em parte no Laboratório Redes de Poder e Relações Culturais da Universidade do Estado do Rio de Janeiro, mediante bolsa concedida pelo Conselho Nacional de Desenvolvimento Científico e Tecnológico (CNPq).

\section{DA GUERRA ANTICOLONIAL À REVOLUÇÃO NACIONAL}

ara o governo francês, a Argélia representava uma extensão do território da metrópole,
uma terra de colonos onde se cultivava a vinha e para onde se enviavam prisioneiros políticos. 0 sentimento de pertencer a uma comunidade nacional foi forjado pela população não europeia em oposição à lei francesa que impunha o repúdio da religião muçulmana aos candidatos à naturalização. Apesar de serem franceses, os argelinos muçulmanos não gozavam de plena cidadania e ocupavam assim uma categoria intermediária entre o estrangeiro e o nacional (Spire, 2004).

O papel da intelectualidade na elaboração da ideia de nação foi ambíguo, já que a administração colonial procurou continuamente dividir a sociedade, buscando até de certa maneira assimilar os letrados. Letrados e intelectuais argelinos eram nascidos na Argélia, porém 
tinham estudado em escolas francesas e muitos desenvolviam suas atividades na metrópole: os primeiros líderes do movimento de reivindicação da igualdade de direitos eram oriundos desse grupo, tinham militado no Mouvement pour le Triomphe des Libertés Démocratiques (MTLD) e tiveram trajetória diversa se deslocando de ideais reformistas para convicções revolucionárias (Stora, 1986: 61).

Acerca da origem social da vanguarda militante, os estudos convergem quanto à sua origem modesta. 0 trabalhador rural fora pouco representado na FLN, que era essencialmente obra de camadas urbanas. Os militantes nacionalistas que aderiram ao levante desde 1954 eram alfabetizados em francês, membros da classe média urbana, artesãos, comerciantes, pequenos proprietários (Carlier, 1995: 286). Ao menos metade dos responsáveis políticos pela propaganda exterior tinha nível superior. Também se estabelece uma distinção com relação aos militantes que se juntaram posteriormente ao movimento, grupo no qual predominavam guerrilheiros com nível de instrução inferior. Ao conquistar a independência, oficiais com ampla experiência na guerra de guerrilhas dirigiam a FLN (Meynier, 2002: 144-147).

Embora seja difícil datar com precisão o surgimento do sentimento nacional, muitos autores concordam em afirmar que os anos 1920 foram determinantes. Entre 1918 e 1939, a natureza árabe e islâmica da Argélia representava o único contrapeso à cultura francesa. A Association des Ulémas Réformistes d'Algérie era aspecto crucial da ideologia nacional, baseada em uma rede de escolas de língua árabe calcadas no modelo francês. Sua principal reivindicação era a reforma religiosa e a restauração da língua sagrada, o árabe. 0 nacionalismo adquiria aqui aspectos de restauração de princípios fundamentais do Islã, tal como teria sido praticado por seus mais antigos fundadores (Vatikiotis, 1966: 333).

A independência seria clamada pela primeira vez em 1927, dentro da comissão coIonial do Partido Comunista Francês (PCF), por Messali Hadj, fundador do movimento Étoile Nord-Africaine. Divisões e lutas fratricidas provocaram a ruptura com o PCF em 1937, e levaram à criação do Parti du Peuple Algérien (PPA-MTLD), movimento oriundo da metrópole, organizado ao redor de trabalhadores imigrantes (Carlier, 1995: 211). Organização radical, sua legitimidade vinha da participação de classes trabalhadoras e populares. Atravessado por fortes tensões internas entre revolucionários e reformistas, o PPA-MTLD congregou parte importante do projeto insurrecional.

Enquanto na Indochina o PCF fizera sabotagens, provocara motins e deserções, dando franco apoio a um movimento dirigido por comunistas, na Argélia o apoio comunista teve menor importância. Desde o fim da Segunda Guerra Mundial o Partido Comunista Argelino (PCA) estava diretamente vinculado ao PCF e seguia orientações de Moscou. Os movimentos de libertação nacional eram encarados como mero instrumento para enfraquecer o campo 
imperialista. O PCA defendia assim o projeto de assimilação da Argélia à nação francesa, ao afirmar que a independência não era a prioridade e estava condicionada à evolução do socialismo na França. O PCA criticou em 1954 a FLN quando esta escolheu a opção armada.

Outro grupo crucial era composto por deputados e políticos representantes do corpo eleitoral dos chamados indigènes. A Assembleia francesa reconhecia a participação de um número reduzido de deputados argelinos, que tinham uma reduzida margem de manobra. Em 1946, o jovem deputado Ferhat Abbas fundou a Union Démocratique du Manifeste Algérien (UDMA), partido político e federação de deputados cujo objetivo era alcançar a autonomia. Sua orientação moderada caracterizava parte importante do nacionalismo argelino (Stora, 2010: 83).

Após o levante fracassado de 1945 e o massacre que se seguiu, muitos militantes passaram a se organizar militarmente. 0 sucesso da Revolução Chinesa (1949) e a vitória da Frente Nacional de Libertação do Vietnã contra o Exército francês (1954) deram força e determinação ao movimento argelino: a vitória sobre as forças colonialistas era possível.

Militantes nacionalistas que combateram junto a franceses durante a Segunda Guerra Mundial se reuniram então na Organisation Spéciale (OS), depois Comité Révolutionnaire d'Unité et d'Action (CRUA), estruturas de formação e de enquadramento militar com o objetivo de consolidar a ideia de independência pelas armas (Carlier, 1995: 271). A FLN argelina surgiu nesse momento e reuniu distintos movimentos nacionalistas em torno da ideia de unidade na luta.

A FLN se opunha a qualquer negociação com a metrópole. Sua estratégia era a guerra de guerrilhas e a busca pelo reconhecimento político internacional. No campo militar, o Exército de Libertação Nacional, braço armado da FLN, encontrou sérias dificuldades: a guerrilha se concentrava no campo e só chegou à capital, Argel, em 1957, quando foi duramente reprimida pelas forças armadas francesas. Durante os oito anos de guerra, apesar dos esforços, a FLN não chegou a controlar nenhuma parte do território nem tampouco alcançou vitórias emblemáticas como a de Dien Bien Phu.

Seus principais quadros foram obrigados a deixar o território, muitos foram presos, outros executados; os demais, desde Túnis, Rabat ou Cairo, comandavam as tropas do ELN que agiam nas regiões desérticas fronteiriças com Marrocos e Tunísia. Diante das dificuldades militares, a FLN orientava cada vez mais sua estratégia para o campo político. No exílio, os líderes argelinos fundaram o Gouvernement Provisoire de la République Algérienne (GPRA) em 19 de setembro de 1958, buscando literalmente tirar a guerra do plano militar e investir na política internacional. Daquele momento em diante, a propaganda exterior se tornaria coerente, antecipando de alguns meses o voto na Assembleia das Nações Unidas, onde a FLN esperava conquistar o reconhecimento internacional (Pervillé, 1982). 
No âmbito da Assembleia das Nações Unidas, um de seus objetivos era alimentar o debate em torno da ilegitimidade da colonização francesa. Para conquistar a atenção do público internacional, a organização nacionalista lançava regularmente ondas de atentados na França e na Argélia.

A FLN pretendia ir além de provocar pressões diplomáticas e buscava mobilizar a solidariedade árabe, causar a comoção dos países não-alinhados e clamar pelo envolvimento dos países latino-americanos. Esperava-se que os emigrantes árabes radicados fizessem pressões sobre os governos de seus países, como também que os militantes anti-imperialistas e revolucionários de todos os países se aliassem à causa argelina.

\section{A REVOLUÇÃo ARGELINA VISTA DO BRASIL (1954-1958)}

té o início da insurreição, em $1^{\circ}$ de novembro de 1954, a Argélia era pouco conhecida
do puco brasileiro e aparecia nas páginas dos jornais em reportagens sobre riquezas minerais, inovações agrícolas, grandes obras de engenharia ou ainda encontros esportivos. A Argélia existia unicamente através da obra dos colonos. A notícia do levante armado surpreendeu. Durante os primeiros meses os principais jornais foram unânimes em denunciar a ofensiva argelina. As informações que chegavam eram oriundas das agências oficiais de notícias, como a Agence France Presse e a United Press, que encaravam o levante como atentados terroristas, atos de banditismo ou, no melhor dos casos, como acontecimentos vinculados à ambição expansionista do presidente do Egito Gamal Abdel Nasser (Distúrbios na Argélia. Movimento Organizado. Exageradas as notícias divulgadas a respeito, 1954).

Uma leitura alternativa dos fatos somente seria publicada pelo jornal Imprensa Popular, que denunciou o que já era, ao ver de seus editorialistas, uma agressão imperialista. Órgão do Partido Comunista Brasileiro (PCB) publicado entre 1948 e 1958, Imprensa Popular, apenas cinco dias após o início da insurreição, se posicionou a favor dos "patriotas da África do Norte" (Luta dos Argelinos contra a dominação francesa, 1954). 0 jornal publicaria ainda nota oficial exigindo o fim do estado de emergência e da repressão colonial, e a normalização das relações entre a França e a Argélia (Resoluções do Comitê Central do PC, 1955).

0 correspondente especial do jornal em Paris, Henri Lesta, denunciava os "métodos dos fascistas franceses que pretendem salvaguardar seus interesses colonialistas na África do Norte", e afirmava que "de nada adiantarão os crimes praticados contra os nossos irmãos marroquinos e argelinos" (Fascismo francês na África do Norte, 1955). Em 1955, a posição do Partido Comunista mudaria com relação à Argélia: o PCA passou a apoiar a luta armada ao criar sua própria guerrilha, Combattants de la Libération, cujo sucesso foi efêmero. Com o 
aval do PCF, dissiparam-se as dúvidas acerca da ilegitimidade da repressão conduzida pelos franceses contra os rebeldes. No entanto, fora dos círculos de discussão comunistas, pouco se sabia sobre a FLN e seus líderes: quais eram seus objetivos, se buscavam a restauração do Estado argelino ou se almejavam a revolução socialista.

Segundo as primeiras declarações dos líderes argelinos, reproduzidas em jornais da época, o objetivo da FLN era conquistar a independência para assim acabar com massacres, torturas e destruições, cujas vítimas eram civis. Os principais problemas levantados foram discutidos também na conferência de Bandung (1955), na Indonésia: direitos humanos, discriminação racial, persistência do colonialismo e direito à autodeterminação dos povos. A FLN lançou de Bandung seu apelo à união dos povos contra o imperialismo e anunciou sua intenção de utilizar a política internacional como instrumento revolucionário (Connelly, 2011: 12). Havia uma nova maneira de pensar a independência nacional que reabilitava teses discutidas pelo humanismo francês.

O papel dos jornalistas foi fundamental para forjar uma nova interpretação do conflito, e cabe aqui insistir no desempenho de Paulo de Castro, aliás Francisco Cachapuz, autor de vários livros sobre colonialismo e socialismo, responsável pela coluna semanal "Momento Internacional" no Diário de Notícias. Exilado da ditadura salazarista, Francisco Cachapuz foi um militante comunista preso pela polícia política do Estado Novo português em 1936. Após sua libertação viajou para a França, colaborou no jornal Le Populaire e, ainda naquele país, se envolveu com as Brigadas Internacionais. Em 1937 partiu para a frente antifranquista espanhola, antes de atravessar novamente a fronteira dos Pirineus, onde foi internado com outros brigadistas no campo de refugiados de Grus e logo no de Argelès, ambos no sul da França (Castro, 1958a: 274). Anos mais tarde, iria para o Brasil, primeiro para São Paulo, depois para o Rio, onde retomou a carreira de jornalista especializando-se em política internacional. Seus livros associavam pensamento político e crítica social.

Sem abandonar suas referências à luta antifascista, Paulo de Castro propunha uma leitura original do conflito. A luta contra o colonialismo era uma extensão do combate contra o fascismo, e nesse sentido citava o deputado francês Pierre Mendès France, ex-chefe do conselho de ministros, afirmando que "o fascismo governa a Argélia" (Castro, 1957a). Passando a ocupar lugar de destaque nos meios jornalísticos brasileiros, cobriria a guerra do início ao fim. Conquistou audiência e renome junto ao corpo diplomático, que lia atentamente seus artigos, muitos dos quais eram reproduzidos nas notas enviadas aos ministros franceses (Hardion, 1958). Sua reputação de jornalista imparcial e a importância de O Diário de Notícias foram fatores que conduziram o governo francês a convidá-lo, em 1957, para uma viagem oficial de 18 dias pela Argélia (L'Algérie et l'Amérique latine, 1959). 
Paulo de Castro foi o primeiro jornalista brasileiro a ir à Argélia. Aproveitou a oportunidade para organizar uma vigem de três meses pela Tunísia, Grécia, Israel, Egito, Síria, lugoslávia, Itália, Alemanha, Bélgica, terminando pela Inglaterra. Durante sua estada de quase um mês na África do Norte, encontrou oficiais do exército colonial que o acompanharam em sua visita a cidades ocupadas pelas tropas francesas na Argélia, enquanto na Tunísia encontrou líderes da FLN exilados (Castro, 1957a). A viagem deixou forte impressão e dúvidas acerca das razões que levaram o governo francês a convidá-lo.

Desde janeiro de 1957, a FLN lançara nova ofensiva, durante a qual foram atacados locais simbólicos, frequentados unicamente por colonos europeus. Também anunciara greve geral enquanto preparava a Assembleia da ONU, onde previa introduzir a questão argelina na pauta de discussões. Seus emissários percorriam o mundo e levavam uma mensagem de luta e independência. A França não podia ficar atrás.

Em 1956, o governo francês votou os plenos poderes ao socialista de Guy Mollet e confiou ao general Jacques Massu, comandante das tropas paraquedistas estacionadas na Argélia, a missão de esmagar a organização rebelde. Durante os primeiros meses de 1957, as ruas desertas da capital, de onde a greve geral tinha tirado todos os muçulmanos, foram imediatamente ocupadas pela elite de oficiais paraquedistas que abriam lojas, derrubavam portas e tiravam pessoas de suas casas, buscando assim acabar com o movimento. As tropas paraquedistas prenderam inúmeros militantes nacionalistas, muitos dos quais seriam torturados e massacrados pelos esquadrões da morte.

Os fatos foram minuciosamente detalhados pelo cineasta Gillo Pontecorvo, militante antifascista italiano, em seu filme $A$ Batalha de Argel (Pontecorvo, 1966). Pontecorvo documentou 0 alto custo humano da guerra e contribuiu para consolidar a imagem de militantes ascéticos, pouco envolvidos com a construção da nação imaginada, mas sempre dispostos a sacrificar suas vidas em nome da revolução (Parker, 2007).

Assim dizia Paulo de Castro: "em pura inocência chegamos a Argel quando se travava uma famosa batalha, que ficaria como uma das grandes páginas da Resistência do povo ao colonialismo [...]. Ao desembarcarmos só encontramos soldados, paraquedistas. Apesar de ter vivido na Espanha republicana durante a guerra civil, [...] nunca tinha visto tanta exibição de força" (Castro, 1971: 7). Paulo de Castro apoiou-se em suas observações diretas para dar um quadro dos problemas que enfrentavam rebeldes e colonos nos desdobramentos do conflito. "O pior desta guerra", dizia, "é que não tem frentes, o inimigo está ao lado e o melhor colaborador dos franceses em muitos casos é um quadro da FLN colocado nesse posto até receber ordem de agir" (Castro, 1957b). Em poucas palavras, essa é a essência da guerra revolucionária: toda a população se envolve no combate contra a metrópole. Enquanto a população 
muçulmana era envolvida na trama de relações pessoais com os guerrilheiros, os colonos europeus viviam isolados. A estratégia francesa era separar as duas comunidades para melhor identificar os rebeldes.

Os resultados de seu périplo pelo Mediterrâneo socialista e revolucionário foram publicados em um livro-panfleto, Terceira força, editado em 1958 pela Editora Fundo de Cultura. 0 livro pretendia fornecer instrumentos de análise da situação internacional, ao pensar os países pós-coloniais capazes de chegar ao socialismo por vias pacíficas. Terceira força e Terceiro Mundo se confundiam no sentido de que reuniam "uma maioria que tenta a sua própria luta pela sobrevivência física, política e moral contra a política dos blocos militares, do imperialismo americano, do sistema totalitário da Rússia, e dos resíduos aviltantes do fascismo" (Castro, 1958a: 14). 0 apoio entusiástico ao movimento nacionalista argelino é inseparável de sua avaliação negativa dos países capitalistas e daqueles de socialismo real. Nem a Europa liberal nem os países comunistas representavam fontes de inspiração para as nações que emergiam das ruínas do colonialismo. 0 livro congrega elementos fundamentais da estratégia dos líderes argelinos que buscavam explorar tanto as contradições do mundo comunista quanto as dos países ocidentais, em busca de sua própria via para o socialismo.

Os acontecimentos na Argélia tiveram forte repercussão na política francesa, provocaram o esgotamento do sistema vigente desde 1946 e a queda da Quarta República. ${ }^{2}$ A instabilidade do regime parlamentar e as contradições do grupo socialista eram fontes de tensão. No entanto, o colapso do regime representa mais que uma crise parlamentar, e a diversidade dos grupos representados no levante ilustra a importância do movimento ultraconservador, já que muitos dos atores da crise provinham da direita e da extrema-direita e estavam envolvidos com a repressão à FLN. Oficiais de contraespionagem, funcionários e políticos eram oriundos de distintas famílias políticas: Résistants, nacionalistas, adeptos do fascismo francês, monarquistas. Os plenos poderes concedidos ao general Massu tinham consolidado a corrente ultraconservadora e um grupo particularmente exaltado de oficiais encontrava expressão para seus projetos contrarrevolucionários na luta contra a FLN.

Paulo de Castro escreveu a esse respeito: "O que hoje se define na França é o resultado de uma luta entre a conspiração e a República, entre os princípios da Revolução Francesa de 1789 e os seus inimigos ontem em Coblez, hoje em Argel. Esmagar, dentro da legalidade republicana, a conspiração é a missão histórica do governo" (Castro, 1958b). A comparação com a Revolução Francesa mostra a que ponto as guerras coloniais dividiam a sociedade. Ao levantar a questão da herança revolucionária de 1789, Paulo de Castro aponta para o problema do direito à autodeterminação dos povos. A guerra da Argélia criava nova ordem, promovida por massas de colonizados, cujo projeto político era o direito à liberdade. 0 sentimento de ter 0 
direito à existência nacional e ao governo do povo, pelo povo e para o povo alimentava 0 discurso sobre a guerra. Os verdadeiros revolucionários se encontravam do outro lado do Mediterrâneo, nos então países do Terceiro Mundo. A exploração colonial e seu caráter totalitário entravam em colapso e com ela o modelo ocidental de democracia.

0 autor apontava também para o problema da contrarrevolução, ao comparar a atitude dos nobres durante a Revolução Francesa com a atitude da elite colonial. Alegava desse modo que existia continuidade no pensamento político da extrema-direita: os ultras da Argélia representariam o anti-humanismo que se opunha aos direitos humanos, ao contrato social, ao individualismo, ao parlamentarismo e ao liberalismo político e econômico. Seus adeptos proliferaram durante os anos 1930, quando rejeitaram os milhões de indivíduos que se tornavam então consumidores e alcançavam o direito de escolher pelo voto seus representantes (Simard, 1988: 62). 0 anti-humanismo estava no cerne das doutrinas totalitárias e suas lógicas de exterminação.

0 problema argelino reunia por si só os principais problemas da França contemporânea e trazia à tona um debate próprio à sociedade francesa, contribuindo para reabilitar tanto o ultraconservadorismo das elites quanto o humanismo da Revolução de 1789.

Paulo de Castro desempenhou papel fundamental na interpretação do conteúdo político da guerra e contribuiu para transformar o modo como eram encarados os militantes nacionalistas. Os que eram até então representados pela imprensa como rebeldes se tornavam revolucionários, e o que era rebelião se tornava revolução.

\section{A propaganda da Frente de Libertação NACIONAL (1958-1962)}

lém de jornalistas locais, a FLN contava também com a atuação de seus militantes,
enviados como emissários a países membros das Nações Unidas. A FLN tinha importantes ramificações em países do Oriente-Médio, no Egito, no Marrocos, na Tunísia, na Iugoslávia e nos Estados Unidos (Connelly, 2011: 323). Os contatos travados entre argelinos no exílio e militantes locais dava à organização capacidade de mobilizar um crescente número de simpatizantes.

O interesse da FLN pela América Latina surgiu em 1955, quando seis dos vinte países latino-americanos votaram a favor da introdução da questão da Argélia na Assembleia da Organização das Nações Unidas. Conquistar a adesão do grupo latino-americano poderia inverter a tendência dominante até então e aumentar as chances de um debate na ONU (Meynier, 2002: 588).

Os primeiros contatos foram estabelecidos no meio estudantil. A Union Générale des Étudiants Musulmans Algériens (UGEMA), fundada em 1955, desempenhou papel fundamental 
nesse sentido, ao enviar jovens aos mais importantes encontros internacionais, onde divulgavam informações, promoviam encontros e organizavam conferências. Fatih Bouayed-Agha chegou ao Brasil nesse quadro, tendo-se matriculado no curso de filosofia da Universidade do Brasil. ${ }^{3}$ Licenciado em Português pela Université de Poitiers, Fatih representou a FLN no Brasil e preparou as visitas de muitos líderes da organização, os presidentes do Governo Provisório como Ferhat Abbas (1957) e Youssef Benkhedda (1960), o vice-presidente da UGEMA Chaib Taleb (1958), e o representante do Crescente Vermelho, padre Alfred Berenguer (1959).

Entre julho e agosto de 1957, Ferhat Abbas, Hassan Trik e Ait-Ahcene percorreram a América Latina em busca de apoio. Abbas era o primeiro líder argelino a viajar pela América Latina, e seu objetivo era sondar a opinião de intelectuais e militantes de esquerda (Meynier, 2002: 588). Os líderes argelinos fizeram um discurso na Associação Brasileira de Imprensa (ABI), no Clube Homs e no XXe Congresso anual da União Nacional dos Estudantes. Por onde passavam, pediam a união dos povos contra a opressão colonial, recorrendo às tradições de luta do povo brasileiro para sensibilizar a opinião pública. Dizia F. Abbas: "acreditamos que os brasileiros, que já lutaram e lutam ainda por sua integral independência se forem esclarecidos sobre a realidade argelina serão incapazes de nos desferir mais um golpe na próxima Assembleia das Nações Unidas" (Líderes do povo argelino pedem o apoio do povo brasileiro à sua luta de libertação nacional, 1957).

A FLN encontraria maior sucesso após a ofensiva insólita do padre Alfred Berenguer. Oriundo de Oran, de família espanhola, Berenguer era eminente figura da Igreja da Argélia, reconhecido por suas posições a favor da FLN. Representante do Crescente Vermelho, por onde passava fundava os primeiros comitês para os refugiados argelinos (Meynier, 2002: 589). Desde a crise de maio 1958, Berenguer atuava fora da Argélia, informando a opinião pública e defendendo os argelinos contra o terrorismo e os refugiados contra a miséria (El Moudjahid, 1959).

Em 1959, Ano Mundial dos Refugiados, sob os auspícios da ONU, Berenguer iniciou uma campanha internacional em prol dos refugiados argelinos. Esteve na Itália, na Espanha, na Suiça e na Alemanha, sendo que desde dezembro de 1958 percorria Uruguai, Argentina, Chile, Brasil, Venezuela, Cuba, Estados Unidos. 0 apogeu de seu périplo foi a recepção organizada pelos guerrilheiros de Fidel Castro na Havana (Boz, 2009: 222-223). Sua campanha teve fortes repercussões e chamou a atenção de políticos brasileiros para a situação da Argélia.

Em 11 de setembro, após sua chegada ao Rio de Janeiro, sob protestos de jornalistas franceses, Berenguer fez uma conferência na ABI. Seu objetivo era pregar a paz e nesse sentido fez um balanço da guerra, que já contava 80 mil soldados franceses mortos, mais 600 mil do lado argelino e quase um milhão de pessoas deslocadas. No Rio a visita ocorreu sem 
incidentes, mas em São Paulo o pároco argelino foi impedido de deixar o aeroporto pelos serviços de informação do consulado francês (El Moudjahid, 1959b). A atuação da embaixada não passaria despercebida e daquele momento em diante jornalistas, deputados da Frente Parlamentar Nacionalista e membros da comunidade Sírio-Libanesa ficariam atentos à situação dos argelinos. A política do governo brasileiro com relação à Argélia seria alvo de críticas, indício de que a propaganda da FLN começava a dar resultados.

Os laços entre os movimentos estudantis brasileiro e argelino começavam também a se fortalecer, deixando maior espaço para que militantes nacionalistas expressassem suas ideias. Em 1960, Taleb Chaib, vice-presidente da UGEMA, visitou o Rio de Janeiro e foi convidado a escrever nas páginas do jornal O Semanário, órgão da Frente Parlamentar Nacionalista. Desde sua fundação, o jornal discutia o envolvimento estudantil com o nacionalismo. As declarações de Chaib caíam como uma luva. Pela primeira vez um líder argelino expunha seus objetivos libertadores.

A colonização querendo chegar a uma despersonalização do povo argelino pelo sufocamento de sua cultura própria, a UGEM se fixa como meta essencial a restauração da cultura nacional. Para atingir esse objetivo primordial, ela deve lutar não somente por uma democratização do ensino e o desaparecimento do analfabetismo, mas sobretudo deve trabalhar por uma mudança radical das estruturas existentes (Chaib, 1960).

A revolução cultural tinha o sentido de volta às origens anteriores à colonização francesa. 0 líder estudantil defendia a restauração do árabe nos currículos escolares e o emprego da língua para consolidar a nação. 0 idioma era forma específica de transformar o país, segundo um projeto distinto daquele imposto pela metrópole. 0 sentimento de injustiça diante da ordem colonial alimentava o nacionalismo, e a identidade nacional surgia em oposição aos valores coloniais.

0 projeto de nação ainda estava pouco claro. Parte da população não tinha o árabe por língua materna, a exemplo dos habitantes da Cabília que participavam ativamente na guerra. Além disso, a Argélia nunca tinha tido existência territorial, o que tornava a unidade cultural o único fundamento possível da nova nação. A cultura era encarada também como instrumento para provar que o país possuía história e civilização próprias, reunindo os principais atributos de uma nação, segundo a própria definição francesa. A transformação da revolta em revolução se fundamentava na exaltação de diferença linguística, religiosa, cultural.

A natureza da revolução argelina seria um dos assuntos mais debatidos naquele ano. Em agosto, chegaram ao Brasil Jean-Paul Sartre e Simone de Beauvoir, convidados a participar do Primeiro Congresso Brasileiro de Crítica e História Literária, na Universidade Federal de 
Pernambuco. Ambos receberam inúmeros convites para dar conferências políticas, literárias e filosóficas. ${ }^{4}$ Uma das principais conferências de Sartre foi dada no Instituto Superior de Estudos Brasileiros (ISEB), diante de um público de mais de 100 estudantes e professores. 0 filósofo francês elucidou pontos de convergência entre as lutas argelina e cubana, assunto que se tornava cada vez mais importante através da colaboração entre guerrilheiros cubanos e argelinos. No entanto, o eixo central de sua fala foi a violência colonial, ao retomar trechos de seu artigo publicado anos antes na revista Les Temps Modernes.

César Guimarães, estudante de direito, próximo do Partido Comunista Brasileiro, e Helena Solberg, estudante de línguas românicas, ambos jornalistas de O Metropolitano, jornal da União Metropolitana de Estudantes, assistiram à conferência e traduziram-na, publicando trechos no jornal estudantil.

A colonização é um sistema [do qual] não é possível sair sem quebrá-lo. Esse sistema traz em si sua condenação à morte. 0 sistema colonial se torna cada vez mais violento porque continua sempre o mesmo, e acaba por usar mais violência contra os homens que submete.

Dois homens compõem o sistema colonial [...]. 0 primeiro é o colono. Ele é incapaz de ceder. Incapaz de conceder. Incapaz de avançar sem a opressão da colônia. É o homem que exige segurança.

O segundo homem da colonização é o colonizado. Ele aparece por sua força negativa. Oprimido, ele vê Ihe repetirem belas coisas, sobre a civilização francesa. E tanto mais oprimido, acaba, por não viver nada desta civilização, a negá-la, uma negação pura. Sabe então que só lhe resta uma possibilidade: sua possibilidade é a morte (Sartre, 1960).

Sartre insiste na violência do sistema colonial, em seus mecanismos econômicos e ideológicos, aspectos que o levam a condenar a ação do Exército francês, encarada como uma ocupação estrangeira. Transmite a ideia de que o homem colonizado só pode libertar-se pela violência. 0 colonialismo é um sistema que recusa ao colonizado qualquer humanidade e, nesse sentido, é semelhante a um sistema totalitário. 0 ímpeto revolucionário finca sua raiz na brutalidade das relações sociais e a violência é o único meio para conquistar a liberdade: era necessário levar a violência revolucionária ao extremo para romper com o sistema. Aí estava exposto o eixo da reflexão de Frantz Fanon, psiquiatra martinicano, editorialista do El Moudjahid, coautor do programa político da FLN (Meynier, 2002: 158).

Sartre antecipava as principais questões levantadas por Fanon ao explorar o problema da violência revolucionária. 0 filósofo do existencialismo apresentava o colonizado como espelho e antítese do colono, a negação do ser, que nega a quem lhe nega a existência. A tomada de consciência da violência colonial era o primeiro passo da reflexão introduzida por 
Sartre e Fanon. Fanon iria além, defendendo que a espiral da violência não tinha volta, ela só poderia crescer, de um lado como de outro (Fanon, 1968: 90).

Os condenados da terra eram produto de cem anos de humilhação coletiva e de permanência de uma ordem dominante fundamentada na separação entre colonos e colonizados. A segregação era vivenciada no cotidiano, na escola, no exército, nos gestos, nas palavras. A luta contra os colonos fortalecia a consciência de pertencer a uma mesma nação, de compartiIhar o mesmo interesse em eliminar ou banir o colono. Os colonizados encarnavam, na Argélia, o combate universal de todos os oprimidos dos então países do Terceiro Mundo. Quando a FLN tomou as armas, direcionou sua violência contra a metrópole e contra os colonos europeus. Guerra popular, a guerra de libertação foi uma revolução porque propunha a destruição da sociedade colonial (Meynier, 2002: 159).

A Argélia era um exemplo de abuso de poder, de opressão colonial, de violência revolucionária. Jornalistas como Wilson Rahal, deputados como Francisco Julião e intelectuais como Paulo Freire comparavam a situação das lutas sociais no Brasil com o combate da FLN na Argélia. Cotidianamente eram publicados textos sobre Patrice Lumumba, Congo Belga, Katanga, Egito e, progressivamente, sobre as colônias portuguesas, cujos movimentos de independência começavam e levantar-se.

A poucas semanas da abertura da XV Sessão da Assembleia das Nações Unidas, Sartre provocou verdadeira comoção no meio intelectual. Apesar da repercussão dos artigos sobre a FLN, sobre Sartre, e das menções à opressão na Argélia, a posição oficial do governo brasileiro se mantinha inalterada: o Itamaraty não reconhecia nem autoridade nem legitimidade aos rebeldes. Em 1960, a maioria dos países ainda se posicionava a favor das metrópoles europeias. Com o intuito de preparar mais uma vez o terreno para as discussões na ONU, a FLN iniciou uma importante ofensiva internacional, com a viagem de seu ministro Youssef Benkhedda por toda a América Latina.

\section{Argel: CAPITAL dA CONTESTAÇÃO}

revolução anticolonial entrava em seu sétimo ano, e era imprescindível que o voto
fovorável à independência, sem compromissos com a França, evitando o quanto possível a partição do país. Desde Nova York, onde se encontravam líderes argelinos, era preparada a excursão pela América Latina. 0 objetivo era discutir publicamente a questão do direito à autodeterminação, fundamento da revolução nacional, e a necessidade de se organizar um referendo monitorado por agentes das Nações Unidas independentes tanto da FLN como da França (Pervillé, 1982). Acreditava-se que a posição brasileira pudesse transformar 
o equilíbrio de forças dentro da ONU. Benkhedda, presidente da comitiva que viajaria pelas Américas, expressava grande otimismo: "há muitos vínculos comuns na tradição anticolonialista dos povos africanos e dos da América Latina. Ambas as regiões tiveram e têm vontade de alcançar a independência nacional" (Missão argelina à América Latina, 1960).

A missão encontraria dificuldades desde antes de chegar ao Brasil, já que a diplomacia francesa estava decidida a impedir que os nacionalistas argelinos obtivessem vistos de entrada nos países pelos quais pretendiam passar. Em Santiago do Chile, a França conseguiu reter Alfred Berenguer, membro da missão. No Rio, a situação também se complicou: a polícia marítima tentou impedir os argelinos de saírem do aeroporto. Graças à intervenção dos embaixadores da lugoslávia, da Indonésia, do Egito e do lêmen, alertados pela UNE, Benkhedda pôde deixar o aeroporto (Lemond, 1960). Ao saírem, Benkhedda e a comitiva argelina foram para o Correio da Manhã, onde fizeram uma primeira declaração, agradecendo a intervenção de diplomatas estrangeiros.

Convidado pelos jornalistas Paulo Silveira e João Dantas, o líder argelino deu nova conferência, desta vez na ABI, acompanhado por dezenas de jornalistas. Segundo El Moudjahid, Benkhedda ainda encontraria o deputado Josué de Castro, seria convidado a pronunciar um discurso na Câmara dos Deputados, conversaria com Dom Helder Câmara e receberia de Roberto Silveira e Frederico Trotta o título de Cidadão do Rio de Janeiro (El Moudjahid, 1960b). Em São Paulo, no Clube Homs, os argelinos projetaram filmes realizados pela FLN, discutiram a situação do país, falaram sobre projetos de governo. Moderado, Benkhedda em nenhum momento revelou suas convicções e se contentou em afirmar não ser comunista nem anticomunista, buscar a liberdade, e, para obtê-la, estar disposto a aceitar ajuda de qualquer país (Benkhedda, 1960).

O Semanário convidou o argelino a publicar uma declaração em que se opunha à política francesa, insistia no apoio já obtido junto a países árabes e socialistas, denunciava a repressão colonial e lembrava que na França começava a se concretizar um movimento formado por estudantes, intelectuais e católicos (Benkhedda, 1960). Mencionou também o lema principal da FLN. Fosse qual fosse seu projeto de nação, não deveria perder de vista que a independência era naquele momento o único objetivo, e para alcançá-la, buscava-se a unidade na constância da luta, solução intermediária que garantia a coesão das forças.

Benkhedda seria mais claro ao tratar do problema da industrialização do país, que só poderia ser realizada mediante a independência política. 0 ministro argelino foi além, ao afirmar que um país subdesenvolvido ou colonizado devia alcançar duas independências: "a independência política, e a segunda independência, a independência econômica e social. 0 objetivo da paz não pode ser um pretexto para que deixemos de lado a imagem que somos 
obrigados a criar da Argélia de amanhã" (Benkhedda, 1960). 0 que estava em jogo era a capacidade do país de atingir novo grau de desenvolvimento, de forma autônoma.

As ideias expostas pelos líderes argelinos caíam como uma luva para intelectuais, estudantes e professores que assistiam às conferências. Muito se discutira acerca das possíveis vias para o desenvolvimento econômico. Otto Maria Carpeaux escreveu anos mais tarde: "os problemas que a Argélia enfrenta são em parte os mesmos que também tem de resolver a América Latina. Os adversários são os mesmos: imperialismo e colonialismo; a independência político-formal precisa ser complementada pela independência político-real, pela independência econômica e pela independência cultural" (Carpeaux, 1965: 2).

Apesar dos encontros com deputados, militantes e intelectuais, os representantes argelinos deixavam o país sem ter encontrado as autoridades brasileiras. Em 1960, o Itamaraty votou mais uma vez contra qualquer intervenção estrangeira no problema da Argélia. A atitude de Brasília provocou uma leva de protestos e o envio de telegramas de solidariedade aos nacionalistas argelinos por parte da Frente Parlamentar Nacionalista. Apesar da grande decepção, dava-se impulso ao movimento de solidariedade à FLN. Emissários argelinos voltariam ao Brasil em 1961 e seriam então recebidos pelo presidente João Goulart, que também não reconheceria a autoridade da FLN.

O governo francês, vitorioso na ONU, buscava uma solução sem negociação com a FLN. De Gaulle propunha a realização de um referendo por meio do qual argelinos e franceses deveriam escolher entre o regime de integração, ou seja, a Argélia francesa, o de associação, quer dizer, uma Argélia intimamente ligada à França, ou o de independência total. Era negada qualquer autoridade à FLN. Por outro lado, a FLN recusava participar, pois temia a intervenção do exército colonial no sentido de forçar a população a votar a favor de uma Argélia francesa: qualquer referendo sem a presença de oficiais das Nações Unidas era recusado.

Dois referendos foram organizados unilateralmente pela França, o primeiro com relativa participação da população argelina de origem não europeia, o segundo marcado pela ausência de grande parte do eleitorado argelino. De Gaulle inspirava-se do referendo organizado nas colônias francesas da África subsaariana, que levara ao enfraquecimento de países como Mali, Senegal e Sudão. A independência da Argélia seria consolidada pelo referendo de abril de 1961. 0 governo francês negociaria então com a FLN as condições de retirada das tropas francesas e de cooperação entre os dois países.

Todos os referendos propostos por de Gaulle provocaram a ira da extrema direita. Em abril de 1960, ergueram-se barricadas em Argel, em oposição à decisão de mudar o comando das tropas coloniais levando o general Massu de volta à metrópole. ${ }^{5}$ Um ano depois, a falta de alternativas conduziu novamente ao surto contrarrevolucionário com tentativa de golpe 
dirigida por comandantes do exército colonial. Afastados de seus comandos na Argélia, condenados à prisão perpétua, muitos oficiais buscaram refúgio na Espanha franquista e formaram no exílio a Organização do Exército Secreto, último recurso para impedir a concretização da independência. Na Argélia, foram destruídas escolas, hospitais, propriedades, bens públicos e privados, levando a população ao pânico. A reação do governo francês foi reprimir a organização clandestina de extrema-direita, deixando claro que a independência era inevitável. Em março de 1962 foram assinados os acordos de paz em Évian e a 5 de julho a Argélia se tornou independente.

A política da terra arrasada praticada pelos últimos colonos que se negavam a deixar o país condicionou os rumos do programa revolucionário. Muitos europeus abandonaram suas terras, principalmente vinhedos. 0 problema da reforma agrária se tornava urgente, a produção agrícola não podia parar e era indispensável que os trabalhadores permanecessem nas antigas propriedades coloniais. A autogestão das terras surgiu neste quadro como um instrumento para administrar antigas fazendas coloniais. Nenhuma solução conseguiu frear 0 êxodo rural e a forte emigração de argelinos.

0 país enfrentava graves problemas. Benkhedda substituíra Ferhat Abbas na direção do Governo Provisório em 1961. Mas o premiê ficou pouco tempo no poder. Com a independência, líderes históricos, entre os quais muitos guerrilheiros, retomavam a liberdade. A unidade no comando seria rompida. Um dos principais líderes, Ben Bella, buscou rapidamente 0 apoio do Exército de Libertação Nacional e de seu chefe de estado-maior, coronel Houari Boumedienne. Benkhedda, coagido, renunciou. F. Abbas assumira a presidência da nova Assembleia Nacional e Ben Bella o poder executivo. As divergências políticas acerca das orientações socialistas do governo começavam a afastar os líderes do antigo Governo Provisório. Após a independência, as bases do socialismo argelino foram lançadas, em meio ao caos social.

Ben Bella tinha a ambição de exportar a revolução a todos os países coloniais ou semicoloniais, coordenando a luta, dando refúgio a guerrilheiros, recebendo militantes e políticos do mundo inteiro, buscando transformar Argel em capital da contestação. A libertação da Argélia não podia parar em suas fronteiras, era uma revolução, e era universal. Pretendia nesse sentido ajudar todos os homens livres do mundo, e ajudá-los ativamente (Manya, 2007: 57). Ben Bella buscava transformar Argel em uma "Meca dos revolucionários", congregando um número cada vez maior de guerrilheiros e militantes que buscavam refúgio, treinamento e armas. 0 primeiro raio de ação da Argélia foi a África, onde se buscava consolidar a posição de movimentos de libertação nacional. Durante esse período muitos cubanos, entre eles Ernesto Che Guevara, foram a Argel, que receberia também militantes do movimento negro 
norte-americano Black Panthers Party (Bloom and Martin, 2013: 314). A Argélia independente passaria a receber militantes revolucionários de distintos países, inclusive brasileiros.

Após o golpe civil e militar de 1964, a intensificação tanto da repressão como da luta armada no Brasil levou ao exílio um número cada vez maior de cidadãos. Em 24 de maio de 1965, Miguel Arraes, ex-governador do estado do Pernambuco, asilou-se na embaixada da Argélia, seguindo no dia 16 de junho para Argel. Levou consigo o jovem Arthur Poerner, que iria escrever um dos importantes testemunhos sobre a revolução argelina. Além de Arraes, João Costa Doria, Márcio Moreira Alves, Almery Bezerra e Everaldo Norões encontrariam Arraes em Argel, fundando a Frente Brasileira de Informações (FBI). A mensagem de luta e liberdade passou a ter repercussões internacionais ao mobilizar rede de militantes que desde as guerras coloniais já lutavam pelos direitos humanos. Retomavam o modelo de luta argelino em que a atuação internacional ocupava o eixo central da estratégia de luta. A articulação da rede de exilados em torno da FBI permitiu, até certo porto, a união dos oposicionistas no exterior.

Em junho de 1970, a Ação Libertadora Nacional e a Vanguarda Popular Revolucionária sequestraram no Rio de Janeiro o embaixador alemão, solto em troca da libertação de presos políticos. Solicitado, o governo argelino concordou em receber 40 prisioneiros políticos, que da embaixada da Argélia seguiram pouco tempo depois para aquele país. Miguel Arraes os estava esperando no aeroporto. A chegada do grupo dos 40 permitiu o encontro dos movimentos brasileiros e africanos. Ao chegar, Apolônio de Carvalho, então militante do Partido Comunista Brasileiro Revolucionário, entrou em contato com a Frente de Libertação de Moçambique para continuar o combate e assimilar a experiência da revolução argelina (Azevedo, 2011: 54).

\section{CONSIDERAÇÕES FINAIS}

s discussões em torno da guerra da Argélia foram intensas e contribuíram para cristali-
zar a ideia de revolução africana. Por outro lado, a revolução argelina participou de um debate sobre as diversas vias para se chegar ao socialismo e, sobretudo, para alcançar a independência nacional. Muitos autores contribuíram para a divulgação dos ideais da revolução argelina. Mais do que um pensamento sobre revolução e socialismo, consolidavam-se laços entre dois universos militantes, fortalecendo a rede de intelectuais e militantes que buscavam solucionar o problema da libertação do homem. A revolução perdia um sentido próprio nacional para tornar-se algo bem mais universal, pois abordava o humano.

Enquanto a viagem de Paulo de Castro pela Argélia revolucionária foi essencial para iniciar o debate no Brasil sobre as condições de emancipação dos povos colonizados, o de Jean-Paul Sartre e Simone de Beauvoir foi fundamental para retomar as ideias acerca do 
caráter revolucionário das massas oprimidas. Ambos contribuíram para internacionalizar a luta anti-imperialista, livre das influências soviéticas.

Os representantes da Frente de Libertação Nacional viajavam pela América Latina, explicando os motivos de sua luta e envolvendo jovens do movimento estudantil e jornalistas em uma trama de relações que levaria muitos a viajar pela África, buscando concretizar ideais de independência nacional. Intelectuais franceses como J.-P. Sartre ou aqueles que viviam nas então colônias francesas, como Frantz Fanon, Albert Memmi, Aimé Césaire, convocavam todos a unir forças contra a opressão, colocando no centro dos debates a figura do colonizado, introduzindo nova bibliografia. Essas discussões acompanharam uma profunda reconfiguração das esquerdas, num momento de crise do modelo comunista.

A propaganda revolucionária da FLN no Brasil encontrou um público cativo. Apesar de ter encontrado pouco respaldo dos dirigentes brasileiros e, por essa mesma razão, não ter alcançado o objetivo de mudar a atitude do Itamaraty nas Nações Unidas, a FLN fortaleceu a solidariedade entre militantes das duas margens do Atlântico. 0 que era um conflito isolado no norte da África entre a metrópole e defensores da independência se tornou uma guerra revolucionária de dimensões internacionais. A descolonização foi antes de tudo uma revolução anticolonial e humana que pôs no centro das reflexões o colonizado, deslocando o centro de atenções dos tradicionais partidos europeus para a África. Era o triunfo de um humanismo francês quase esquecido.

Antes da independência da Argélia, somente alguns poucos jornalistas haviam percorrido os países africanos e travado contato com guerrilheiros africanos. Após a independência, Argel se tornou um local de convergência de lutas. Argel se tornou assim o epicentro de militantes revolucionários não somente na África de língua portuguesa, mas também na América Latina, com a presença de inúmeros cubanos que de lá partiram em direção a outros países, como o Congo, para exportar a revolução.

A estratégia de independência que adotara a FLN, ao associar guerrilha interna e propaganda política internacional, teria fortes repercussões na maneira como determinados movimentos sociais de extrema esquerda desenvolveriam suas atividades, como foi o caso da Organização para Libertação da Palestina (OLP), do Partido dos Panteras Negras nos Estados Unidos, ou ainda dos movimentos dissidentes do partido comunista.

As lutas de independência na Argélia foram importantes porque, além de fornecerem uma forte crítica ao colonialismo, possibilitaram pensar os sistemas de dominação de forma crítica e em uma perspectiva transnacional. 


\section{NOTAS}

1 Em árabe, moudjahid são os soldados do exército de libertação nacional.

20 levante de maio de 1958 começou após cerimônia em Argel em homenagem a dois soldados do Exército colonial executados pela FLN. A cerimônia se transformou em ato público e depois em passeata, culminando na formação de um comitê de salvação pública dirigido por militares cujo projeto era derrubar o governo socialista. 0 levante reuniu líderes políticos, jornalistas, militares e ativistas, que tinham pouco em comum, mas compartilhavam o objetivo de opor-se à política colonial do recém-nomeado chefe do governo francês Pierre Pflimlin.

3 Quando foi expulso do Brasil, em agosto de 1967, pelo governo Castelo Branco, O Correio da Manhã publicou uma ficha biográfica de Fatih Bouayed-Agha, que atuava então como ministro conselheiro do governo argelino. 0 jornal carioca indicava que o diplomata argelino chegara ao Brasil em 1954, como representante de imprensa. No entanto, segundo as Nações Unidas, onde Fatih atuou como diplomata, o argelino chegara ao Brasil como representante do jornal El Moudjahid em 1955, ocupando esse cargo por oito anos.

4 A viagem de Sartre e Simone de Beauvoir ao Brasil foi amplamente documentada e discutida em jornais e revistas, tanto da época como atuais, aos quais remetemos o leitor.

5 Jacques Massu comandou as tropas paraquedistas francesas estacionadas na Argélia de janeiro de 1957 a setembro de 1961. Após discurso do presidente Charles de Gaulle em que este defendia a organização de referendo sobre a autodeterminação da Argélia, Massu declarou à imprensa alemã que o Exército não compreendia a política do governo. Condenado por ter ultrapassado seu dever de reserva, Massu foi transferido para a metrópole. Para aqueles que defendiam o projeto da Argélia francesa, Massu representava a última alternativa para defendê-lo. Sua mudança de cargo e logo seu deslocamento para a metrópole conduziram à semana das barricadas, o primeiro levante da extrema direita.

\section{REMISSÕES BIBLIOGRÁFICAS}

ANDERSON, Benedict. Comunidades imaginadas: reflexões sobre a origem e a difusão do nacionalismo. São Paulo: Companhia das Letras, 2008.

Argelino: De Gaulle alimenta a guerra. Tribuna da Imprensa, Rio de Janeiro, 5-6 de novembro de 1960, p. 2.

AZEVEDO, Desirée de Lemos. Os melhores anos de nossas vidas. Narrativas, trajetórias e trajetos de exilados brasileiros, que se tornaram cooperantes na República Popular de Moçambique. Campinas: Universidade Estadual de Campinas, tese de doutorado, 2011.

BAILBY, Edouard. 0 dilema da Argélia. O Semanário, 6 de julho de 1962, p. 2.

BENKHEDDA, Youssef. Trágico balanço do regime de terror implantado na Argélia pelos colonialistas franceses. O Semanário, 12-18 de novembro de 1960, p. 4.

BLOOM, Joshua \& MARTIN, Waldo. Black against empire: the history and politics of the Black Panther Party. Berkeley: University of California Press, 2013.

BOZ, Pierre. Une fin des temps. Fragments d'histoire des chrétiens en Algérie. Paris: Desclée de Brouwer, 2009. 
BRANCHE, Raphaëlle (org.). La guerre d'indépendance des Algériens 1954-1962. Paris: Presses Nationales de la Fondation des Sciences Politiques, 2009, p. 59-73.

CARLIER, Omar. Entre nation et djihad. Histoire sociale des radicalismes algériens. Paris: Presses de Sciences Po, 1995.

CARPEAUX, Otto Maria. Prefácio. In: Poerner, Arthur José. Argélia: o caminho da independência. Rio de Janeiro: Civilização Brasileira, 1965.

CASTRO, Paulo de. Cada dia de guerra aumenta a separação de franceses e muçulmanos. Diário de Notícias, Primeira Seção, p. 1, 16 de dezembro 1957a.

- Apesar de todos os erros os argelinos preferem entender-se com os franceses. Sacerdotes católicos, jornalistas e professores defendem os muçulmanos. Diário de Notícias, Primeira Seção, p. 1, 19 de dezembro $1957 b$.

—_. Terceira força. Rio de Janeiro: Editora Fundo de Cultura, 1958a.

—_. Dias decisivos para a França. Diário de Notícias, Primeira Seção, p. 4, 18 de maio 1958b.

—_. A grande conspiração. Diário de Notícias, Primeira Seção, p. 4, 27 de maio 1958c.

—_. Visita do Padre Berenguer. Diário de Notícias, Primeira Seção, p. 4, 9 de setembro de 1959.

—. Argélia, a terra e o homem. Rio de Janeiro: Fórum Editora, 1971.

CAUBET, Rosa Alice. La bibliographie brésilienne de Sartre. Fragmentos. Florianópolis: Editora da UFSC, n. 2, 1986, p. 59-73.

CHAIB, Taleb. Os estudantes, a cultura argelina e o colonialismo. O Semanário, 16-22 de janeiro de 1960, p. 9.

Conferência coletiva de líderes argelinos. Diário de Notícias, 30 de julho de 1957, Primeira Seção, p. 2.

CONNELLY, Matthew. L'arme secrète du FLN. Comment de Gaulle a perdu la guerre d'Algérie. Paris: Payot \& Rivages, 2011.

Distúrbios na Argélia. Movimento organizado. Exageradas as notícias divulgadas a respeito. Correio da Manhã, 2 de novembro de 1954, p. 1.

Duzentos mil civis já morreram na Argélia! Última Hora, 31 de julho de 1957, p. 6.

El Moudjahid. La délégation de I'UGEMA à travers I'Amérique Latine. Belgrade: réédition de Belgrade, 1962, t. 1, n. 41 (1959a).

El Moudjahid. Les services de contre-espionnage français à São Paulo. Belgrade: réédition de Belgrade, 1962, t. 2, p. 564 (1959b).

El Moudjahid. Le Brésil ne peut trahir la liberté. Belgrade: réédition de Belgrade, 1962, t. 3, p. 406 (1960a).

El Moudjahid. La mission du GPRA au Brésil. Belgrade: réédition de Belgrade, 1962, t. 3, p. 341-342 (1960b).

FANON, Frantz. Os condenados da terra. Rio de Janeiro: Civilização Brasileira, 1968.

FITTE, Albert. Spectroscopie d'une propagande révolutionnaire. El Moudjahid du FLN des temps de guerre. Montpellier: Presses de I'Université Paul Valéry, 1973. 
HARDION, Bernard. Considérations de la presse brésilienne sur les événements de France et d'Algérie. 31 de maio de 1958. Paris: Archives du Ministère des Affaires Étrangères et Européennes. Caixa 45.

JULIÃO, Francisco. A luta dos camponeses do Engenho da Galileia repercute na Câmara. O Semanário, 22 de janeiro de 1960, p. 6.

LEMOND, Henri. Compte rendu mensuel: réaction aux événements d'intérêt français. Outubro de 1960. Vincennes: Service Historique de la Défense. Caixa10T1112.

Réaction aux événements d'intérêt français. Novembro de 1960. Vincennes: Service Historique de la Défense. Caixa $10 \mathrm{~T} 1112$.

LESTA, Henri. Fascismo francês na África do Norte. Imprensa Popular. 30 de dezembro de 1955, p. 3.

Líderes do povo argelino pedem o apoio do povo brasileiro à sua luta de libertação nacional. Imprensa Popular, 27 de julho de 1957, p. 1.

MANYA, Judith. Les Portugais d'Alger 1962-1974. In: Nouvelles perspectives de la recherche française sur la culture portugaise. Clermont-Ferrand: PUBP, 2007, p. 51-59 [http://pubp.univ-bpclermont.fr/public/pdf/Nouvellesperspectives.pdf].

MEYNIER, Gilbert. Histoire intérieure du FLN 1954-1962. Paris: Librairie Arthème Fayard, 2002.

Missão argelina à América Latina. Correio da Manhã. Rio de Janeiro, 14 de setembro de 1960.

Padre Berenguer a UH: Federação Africana colaboraria com França. Última Hora, 14 de setembro de 1959.

Padre francês que defende argelinos acusa a França de guerra injusta. Jornal do Brasil, 12 de setembro de 1959.

PARKER, Mark. The Battle of Algiers (La battaglia di Algeri). Film Quarterly, 2007, v. 60, n. 4, p. 62-66.

PAULO, Heloisa. 0 republicanismo e a oposição exilada: combates e crises. Estudos do Século XX. Coimbra: Imprensa da Universidade/Ceis 20, n. 11, 2010, p. 423-436.

PERVILLÉ, Guy. L'insertion internationale du FLN algérien (1954-1962). Relations Internationales. Genebra, 1982 , n. 31, p. 373-386.

—. La révolution algérienne et la guerre froide (1954-1962). Études Internationales, 1985, v. 16, n. 1, p. 55-66.

L L'élite intellectuelle, I'avant-garde militante et le peuple Algérien. Vingtième Siècle, Revue d'Histoire. Paris, 1986, v. 12, n. 1, p. 51-58.

POERNER, Arthur José. Argélia: o caminho da independência. Rio de Janeiro: Civilização Brasileira, 1965.

Resoluções do Comitê Central do PC Francês. Imprensa Popular. 17 de julho de 1955, p. 5.

SARTRE, Jean-Paul. Colonialismo, um sistema por explodir. Diário de Notícias, 4 de setembro 1960. O Metropolitano, p. 56.

—. Prefácio. In: FANON, Frantz. Os condenados da terra. Rio de Janeiro: Civilização Brasileira, 1968.

SIMARD, Marc. Intellectuels, fascisme et antimodernité dans la France des années trente. Vingtième Siècle, Revue d'Histoire. Paris, 1988, n. 18, p. 55-76. 
SPIRE, Alex. Semblables et pourtant différents. La citoyenneté paradoxale des "Français musulmans d'Algérie" en métropole. Genèses, 2003/4, n. 53, p. 48-68.

STORA, Benjamin. Faiblesse paysanne du mouvement nationaliste algérien avant 1954. Vingtième Siècle, Revue d'Histoire. Paris, 1986, v. 12, n. 1, p. 59-72.

Le nationalisme algérien avant 1954. Paris: CNRS Éditions, 2010.

VATIKIOTIS, Panayiotis Jerasimof. Tradition and political leadership: the example of Algeria. Middle Eastern Studies. 1966, v. 2, n. 4, p. 330-366. 